\title{
A GREAT SCHOLAR, METHODOLOGIST AND TEACHER
}

Tagir Shamsegalievich Gilazov, Kazan Federal University, 18 Kremlyovskaya Str., Kazan, 420008, Russian Federation, tgilazov@bk.ru.

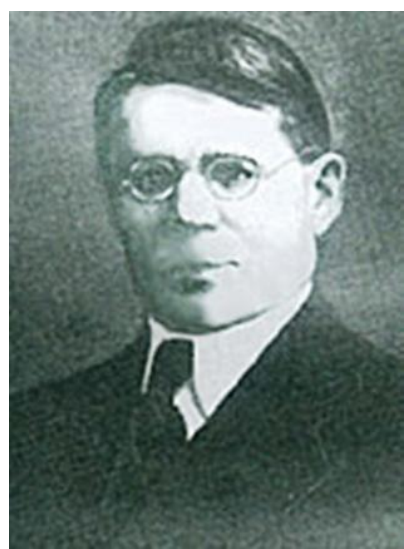

Sagdiyev Gabdrakhman Gainanovich (Gabdrakhman Sagdi) (27(14).03.1889-06.11.1956) was born into a religious family in the village of Taymi (Taimi), the Zlatoust county of the Ufa province (currently the Salavat district in the Republic of Bashkortostan). He became a famous literary critic, linguist, and methodologist.

In 1902-1905, he was a student of the madrasah "Rasuliya" in Troitskiy. In 1908-1911, he studied at Turkish State University in Istanbul. He worked as a teacher in Tatar madrasahs (1911-1917) in different parts of Russia: in Bugulma in 19171921, in Central Asia in 1921-25. In 1926, he was a docent of the Kazan Eastern Pedagogical Institute. He was one of the founders of the Tatar Language and Literature Department, Professor of Literature Instruction (1929). In the Educational Center he worked in cooperation with such societies as "The History of the Tatar people" and "Tatar Studies", based in the Academic Center. He was a teacher of Tatar literature at Tatar Communist University and in the Pedagogical College (1925-1930).

In 1930, he was a teacher at the Department of Uzbek Literature at the Samarkand Pedagogical Academy, from 1930 he was a Professor at the Higher Educational Institutions
Габдрахман Гайнан улы Сәгъдиев (Габдрахман Сәгъди) (27(14).03.1889-06.11.1956) Уфа губернасы Златоуст өязе Морзалар волосте (хәзерге Башкортстан Республикасы Салават районы) Таймый (Таими) авылында рухани гаиләсендә туа. Күренекле әдәбият галиме, лингвист,

1902-1905 елларда Троицк шәһәрендәге "Рәсүлия" мәдрәсәсе шәкерте. 1908-1911 елларда Истанбулда Төркия дәүләт университетында белем ала. Актүбә (1911-13), Алма-Ата (1913-14), Екатеринбург (191415), Ыргыз (1915-16) шәһәрләре һәм Таймый авылы (1916-17) мәдрәсәләрендә, 1917-21дә Бөгелмә шәһәрендә, 1921-25тә Урта Азиядә укыта.

1926 елда Казан Көнчыгыш педагогия институты доценты, анда татар теле һәм әдәбияты кафедрасын оештыручыларның берсе, әдәбият методикасы профессоры (1929); Гыйльми Үзәк каршындагы “Татар жәмгыяте тарихы”, “Татарларны өйрәнү” жәмгыятьләре белән хезмәттәшлек итә; Татар Коммунистлар университетында, педагогия техникумында татар әдәбияты укытучысы (19251930). методист.
Габдрахман Гайнанович Сагдиев (Габдрахман Сагди) (27(14).03.1889-06.11.1956) известный литературовед, лингвист, методист - родился в семье муллы в деревне Таимиево Мурзаларской волости Златоустского уезда Уфимской губернии.

В 1902-1905 гг. - шакирд медресе «Расаиля» в городе Троицк.

В 1908-1911 гг. - студент Стамбульского государственного университета.

Работал преподавателем в татарских медресе г. Актюбинска (1911-1913), Алма-Аты (19131914), Екатеринбурга (19141915), Иргиза (1915-1916), деревни Таймиево (1916-1917).

В 1921-1925 г. читал лекции на рабочем факультете Среднеазиатского государственного университета, военной школе им. Ленина, тюрко-татарском институте просвещения. В 1926 г. он избирается доцентом, в 1931 г. - профессором Восточнопедагогического института в Казани, организует кафедру татарского языка и литературы, кабинет литературы.

В 1925-1930-х гг. сотрудничал с «Обществом татарской педагогики», «Татароведением», организованными на базе Академического Центра.

Автор более 30-ти трудов по 
of Tashkent, later, in 1933, he became the head of the Department of the Uzbek Language and Literature and Professor of Uzbek literature at the Pedagogical State Institute of Fergana. In 1937-1941, he was the head of the Department of Uzbek literature at Uzbek State University in Samarkand, from 1940 he was a Professor at the Department of Uzbek Literature, in 1942, he became the head of the Department of Uzbek Language and Literature at Central Asian State University in Tashkent. In 1939-1944, he worked in the Uzbek branch of the USSR Academy of Sciences and in the Academy of Sciences of the UzSSR at the Institute of Language and Literature in 1944-1949. On October 6, 1949, he presented his doctoral thesis on "The works of Navoi as the highest stage in the development of classical Uzbek literature". In 1950, Sagdi received the degree of Doctor of Philology. He was the holder of the Order of the Red Banner of Labor (1946), awarded by the Presidium of the Supreme Soviet of the USSR, and an honorary diploma of the Presidium of the Supreme Soviet of the UzSSR.
Татар һәм үзбәк әдәбиятлары тарихы, тел һәм әдәбиятны укыту методикасы буенча 30дан артык хезмәтләр авторы.

1930да Сәмәрканд Педагогия академиясенең үзбәк әдәбияты кафедрасында укытучы, 1932 елдан Ташкент югары уку йортларында профессор, 1933тән Фирганә дәүләт педагогия институтының үзбәк теле һәм әдәбияты кафедрасы житәкчесе hәм үзбәк әдәбияты профессоры. Сәмәркандтагы Үзбәкстан дәүләт университетының үзбәк әдәбияты кафедрасы мөдире (1937-1941), 1940тан үзбәк әдәбияты кафедрасы профессоры, Ташкенттагы Урта Азия дәүләт университетының үзбәк теле һәм әдәбияты кафедрасы житәкчесе (1942дән), 1939-1944 елларда СССР ФАсенең Үзбәкстан филиалында, 1944-1949 елларда ҮзССР ФАсенең Тел-әдәбият институтында хезмәттәшлек итә. Филология фәннәре докторы гыйльми дәрәжәсенә дәгъва иткән "Үзбәк классик әдәбияты үсешендә югары этап буларак Нәвои ижаты" дигән темага диссертация яклый (1949 елның 6 октябре). Г.Сәгъди 1950дән филология фәннәре докторы. СССР Верховный Советы Президиумы тарафыннан бирелгән "Хезмәт Кызыл Байрагы” ордены (1946), Үзбәкстан ССР Верховный Советы Президиумының Мактау грамоталары иясе. истории татарской и узбекской литературы, методике преподавания литературы.

В 1930-м году преподавал в Самаркандской педагогической академии. В 1932 г. работал в должности профессора в высших учебных заведениях г. Ташкента. В 1933 г. возглавил кафедру узбекского языка и литературы в Ферганском государственном педагогическом институте.

В 1937-1940-х г. возглавил вновь созданную кафедру узбекской литературы в Самаркандском государственном университете в Узбекистане. В 1942 г. стал заведующим кафедры узбекского языка и литературы Среднеазиатского государственного университета в Ташкенте.

В 1939-1944 г. сотрудничал с Узбекским филиалом АН СССР, в 1944-1948 г. - с Институтом языка и литературы АН Узбекской CCP.

6 октября 1949 г. защитил докторскую диссертацию «Творчество Навои как высший этап в развитии узбекской классической литературы» и стал доктором филологических наук. Награжден Орденом Трудового Красного Знамени (1946), Почетными грамотами Президиума Верховного Совета Узбекской ССР.
Sagdiyev Gabdrakhman Gainanovich (Gabdrakhman Sagdi) was born on March 27(14) 1889 into a religious family in the village of Taymi (Taimi, the previous name was Atau), the Zlatoust county of the Ufa province (currently the Salavat district in the Republic of Bashkortostan). Despite the fact that his father, Gainan Haji, was an educated and intelligent man who opened a library in his village and a teacher too, he did not approve of his youngest son Gabdrakhman's passion for learning and gaining knowledge. Against his father's will, the boy began to attend a village school. Love for learning inspired strength and illuminated the dark life of the boy, who was driven out of his house because of his perseverance. In 1902, he en- tered the madrasah "Rasuliya" in Troitskiy. Deprived of any financial assistance, the teenager earned money firstly by helping more wealthy students, and later, during the holidays, he was hired by rich Kazakhs. The desire for enlightenment, his wisdom and language proficiency began to bear fruit: Gabdrakhman taught those who knew less, acquiring his first teaching experience.

In 1908-1911, he graduated from the Philological Department of Turkish State University, after completing the course in the "History of TurkicTatar Literature", as well as other fields of knowledge. Years of study at the University opened G. Sagdi's eyes: he understood that without changing the educational system it would be im- 
possible to achieve spiritual and social revival of the Tatar people, their cultural development. In this regard, he could be placed on a par with such famous enlighteners as Kayum Nasyri, Ismail Gasprinsky, and Fatih Karim. In 1910, G. Sagdi wrote the article "Teaching Literature in Madrasahs", which outlined the main problems to be solved in the near future. He wrote about the representatives of national intellectuals, outlining his mission too. Tukay called him 'warm' and 'sacred', the 'light of the ideal', which not only illuminated their lives, but also determined the direction of their further work and inspired them to serve their nation [Tukai, p. 280].

G. Sagdi, who set high goals after returning from Turkey, started working hard and annually published either a teaching manual or a monograph.

In his works, Sagd examined literature as a form of art, its essence, tasks, types, and genres, its composition and story, as well as other relevant issues: "Мохтәсар къәвәгыйде әдәбия" (The Summary of Literature) (1911), "Гыйлавә" (Addendum) (1911), “Әдәбият ысуллары” (Methods of Literature) (1912), “Әдәбият мөгаллиме” (Researchers of Literature) (1913).

These issues are discussed in Sagdi's textbooks and in the samples from Turkish books. His theoretical views were influenced by his education in Turkey, the study of Arabic-Persian languages, the foundations of the Turkish language and literature, the comprehension of Turkish literature and literary thought, and the study of the works of Eastern scholars.

G. Sagdi's textbooks caused great controversy in the period of aggravation of Tatar-Russian and Tatar-European cultural relations. He defended his position and published dozens of articles in mass media. To share his pedagogical experience, he contributed a series of scientific and methodological articles to the journal 'Shura' for those who were interested in teaching literature and language.

The scholar would not stop working. He wrote textbooks for schools and madrasahs promoting advanced ideas for different stages of the new educational trend on such subjects as spelling, morphology and syntax. He was also interested in etymology. "Телебезнең нәхүе" (Syntax of Our Language) (1914), "Үз телебездә мөкәммәл сарыфнәху" (Talented Morphology and Syntax in Our Language) (1915) are the examples of his studies in this area.

G. Sagdi met the October Revolution of 1917 in Bugulma doing three-month Tatar-Bashkir ped- agogical courses. This period of his life was characterized not only by scientific and pedagogical activity, but also by his active organizational work. Owing to his efforts, this period of training was increased to a three-year pedagogical course, laying the foundations of the Bugulma Pedagogical Seminary. For four years, along with teaching literature, pedagogy, methods of teaching language and literature, he wrote textbooks "Фәне тәрбия тәгълим" ("Lessons of Pedagogy”) (1918), “Фәне тәрбия вә тәгълим" ("Pedagogy and Didactics") (1918), which led the scholar from Philology to other areas of science. As mentioned in the title, the last textbook reveals the essence of such notions as: the formation of pedagogy, its development, stages, branches and connections with other sciences, the theory of upbringing, the laws of didactics, forms and methods of education, and other issues [Gyiləжеva, p. 21].

The burden of responsibility and hard work throughout those years led to deterioration of $\mathrm{G}$. Sagdi's health. In order to improve it, he went to the Caucasus and returning to work after treatment, he stopped in Baku to deliver lectures at short-term pedagogical courses. The same year in autumn, the People's Commissariat of Education in Turkmenistan invited him to work in the pedagogical sphere in Tashkent. In 1921-1925, G. Sagdi lived in Tashkent and taught language and literature in the Eastern Institute of Education opened for the Turkic peoples, at Workers' Faculties and in Central Asian State University. He published literary and critical articles on the history of Turkic literature in newspapers and magazines simultaneously in the Uzbek, Kazakh, Turkmen, and Tatar languages. [Dautov, Rakhmani, p.350].

In the autumn of 1925 , G. Sagdi returned to Kazan at the invitation of the Tatar Central Executive Committee. According to some reports, G. Ibrahimov, who highly appreciated the theoretical education of the scientist and the depth of his mental potential, initiated this arrival. This fact, in its turn, made friendly and creative relationships between G. Sagdi and G. Ibrahimov stronger, accelerated the scientist's progress in mastering the methodology of research and literary criticism. Until 1930, he taught the history of Tatar literature in Tatar Communist University and in the Pedagogical College. In 1926, Sagdi was elected Associate Professor of the Kazan Eastern Pedagogical Institute, the only tertiary institution, providing education for teachers of the Tatar language and literature. This expanded the horizons of scientific and organizational activities for Sagdi, allowing him to 
further his research. Here, he organized the Department of the Tatar language and literature and opened a literature office. He conducted lectures in linguistics, literary studies, methodology, and pedagogy. By involving talented and motivated young people in research activities, he made a huge contribution to the development of the philological trend and provided research institutes with new personnel.

In 1920-1930, G. Sagdi became a well-known and versatile literary critic. His book "The History of Tatar Literature" (1926) can be rightfully regarded as a scientific achievement, determining a new way of the scientific development. It was a textbook for students of philological faculties in higher educational institutions. The book met all the requirements for monographs on the study and evaluation of the history of literature.

G. Sagdi worked both on monographs on the history of literature, and on other important issues of literature instruction as well as on the works of some prominent authors. He published his research results in various newspapers and magazines, including 'Bezneng Yul', 'Magarif' and 'Kizil Tatarstan'. In his articles, he explored biographical facts, professional development and stylistic choices of such acclaimed authors as G. Tukay, G. Ibrahimov, F. Amirkhan, S. Ramiev, G. Kulakhmetov to name a few.

In the books, published in 1910, G. Sagdi, along with his contemporaries, ventured into the world of literary criticism and its theoretic studies [Gyilaжev, p. 430]. In 1927, he discussed this subject in a monographic article titled "Our Literary Criticism (On the $10^{\text {th }}$ Anniversary of the October Revolution)" [Sagdi, 1927] and the very same year published it in the form of a small booklet. Although in this article he tried to analyze the origins and history of criticism and poetical issues through the prism of Marxism, he became one of the first to systemize its genesis and historical development. In addition, the author explored literary criticism as an area of academic study, compared it with literary fiction and created a classification for different types ('philosophical', 'philological') and movements of criticism ('realistic', 'idealistic' (romantic, esthetic)), based on the rules and principles of literary criticism.

The year of 1932 marked the creation of an outstanding piece called "On Symbolism" where G. Sagdi proves that literary fiction can be studied through the context of various cultural, esthetic, and philosophical systems. The fact that this monograph was later published by the central publish- ing house in Moscow testifies to the academic value of this work. Thus, it is described as a major achievement both for the author himself and for Tatar literary studies in general, in spite of all the challenges of that period.

Regardless of the fact that in his public speeches and his academic works G. Sagdi evaluated authors and their literary works through the prism of Marxist and Leninist esthetics, the tensions that started to grow in the literary and academic community in the late 1920s resulted in accusations of horrific crimes brought against G. Sagdi. His works were analyzed for ideological deviations, which made the scholar seek his salvation in migration to Central Asia.

In 1930, G. Sagdi moved to Samarkand and started his teaching and academic work in the Pedagogical Academy of Samarkand. In two years' time, he opened the Uzbek Literature Department and worked towards organizing the Language and Literature Faculty. He did not merely deliver lectures, but also encouraged his students to try their hand at academic work and writing. Resourceful and hard-working, Sagdi gave talks at various scientific research conventions and conferences, thus contributing to the development of Uzbek literary studies. All his written pieces and talks of that period and up to the 1930s were later compiled in a book under the title "Problems of Literature and Uzbek Literature after the October Revolution" (1931). Having received recognition for his interesting and witty works, and well-grounded academic research, G. Sagdi got invited to Tashkent in 1932, where he continued his pedagogical work in various higher educational establishments.

From then on, the People's Commissariat for Education of the Uzbekistan SSR used the active, energetic and well-educated G. Sagdi at the most challenging locations. In the fall of 1932, he was sent to the Firgana National Pedagogical University, where he was given a degree in Uzbek Literature and a task was set to organize the Department of Uzbek Language and Literature, which he headed for four years. As his work was highly appreciated, G. Sagdi was able to receive the Candidate of Sciences degree without presenting a thesis and once again became a professor of Uzbek literature. G. Sagdi continued his research on the history of Uzbek literature and its methodology, and published several books, including "Literature Study Guide" (1933), "Uzbek Bourgeois Literature" (1934), "The Main Issues of Teaching Literature in Middle School" (1943), and "Navoi. A Literary Theorist and Critic" [Sagdi, 2008, p. 44]. 
However, due to some miscommunication, Sagdi was forced to leave his position at the institute and return to Samarkand University, where he, once again, rolled up his sleeves and resumed his educational, organizational, teaching and academic activities. In 1937-1941, he headed the Uzbek Literature Department of Uzbek National University, where he delivered well-grounded and highly informative lectures on the history of literature in the context of Eastern philosophy and Greek culture all in fluent Uzbek. But, with the beginning of the Great Patriotic War, Samarkand University had to merge with Central Asian National University in Tashkent, so G. Sagdi had to move to Tashkent. Once again, in 1942, he was assigned an incredibly important task of heading the Department of Uzbek Language and Literature and preparing new academic personnel in linguistics and history of Uzbek literature. In 1946, G. Sagdi officially received an academic rank of Professor and the Order of the Red Banner of Labour for his dedicated service.

Besides his educational and methodological work at the university, Sagdi worked in close cooperation with the Uzbekistan Branch of the USSR Academy of Sciences in 1939-1944 and with the Institute of Language and Literature at the UzSSR Academy of Sciences in 1944-1949. On October 6, 1949, he presented his doctoral thesis "The Works of Navoi as the Highest Point in the Development of Uzbek Classic Literature" at the session of the Academic Council of the Institute of Oriental Studies in Moscow. On April 22, 1950, by order of the Higher Attestation Commission, G.Sagdi received a doctorate degree [Gyiləжеva, p. 35].

Although life, social-historical events and political circumstances forced G. Sagdi to move to another country and work towards developing Uzbek scientific research and culture, he always displayed interest in the fate and literary-cultural life of the Tatar people. In the last years of his long but complicated life, he expressed a desire to return to his homeland, but unfortunately, he never did. In 1952, under the instructions from the USSR Ministry of Education, G. Sagdi was assigned a professor of Uzbek literature in Uzbek National University, where he worked until the end of his life.

The multitalented scholar M. Gosmanov drew a parallel between G. Sagdi's "rough, hard and tragic" life and the complicated history of the Tatar people and, in a wide sense, called it 'an instance of our historical fate' [Gosmanov, p. 3]. Therefore, the prominent philologist, turkologist, methodolo- gist and educator G. Sagdi, having survived the years of Stalin's Personality Cult, became one of the most outstanding figures of his nation, who made major contributions to the development of Tatar academia and its culture. In the early $20^{\text {th }}$ century and starting from the 1930s until the end of his life, he worked for the development of the Turkic (Turkman, Kazakh, Azerbaijan) and, especially, Uzbek literary and linguistic studies, improving the methods of their teaching in universities and other higher educational institutions, and prepared a new generation of scholars and researchers.

\section{References}

Galiieva, E. R. (2002). Tatar adabiyat belemenda kul'tura-tarikh maktabe [The Cultural-Historical School of Tatar Literary Criticism]. 360 p. Kazan, Fen. (In Tatar)

Gosmanov, M. G. (2008). Tarikhi yazmyshybyzny ber kyypylchygy syman [Like an Instance of Our Historical Fate]. Gabdrakhman Səg"di: fənni-biografik жyyentyk / tez. D.Zahidullina, Ch.Gyilaжeva. Pp. 3-6. Жyyen. (In Tatar)

Gyilaжev, T. Sh. (2016). “Әdabiiat belemenę̧ ber tarmagy bularak adabi tənkyit" [Literary Research as a Branch of Literary Criticism]. Tatar dəibiiat tarihy: signi tomda: $4 \mathrm{t} . \therefore$ XX yuz bashy. (s. R. F. Rahmani; fənni meh. R. K. Ganieva). Pp 428-453. Kazan, Tatar.kit.nəshr. (In Tatar)

Gyiləжеva, Ch. M. (2012). Odabiiat fane ham Gabdrakhman Sag"di [Literary Studies and Gabdrakhman Sagdi]. 208 p. Kazan, RITS. (In Tatar)

Dautov, R.N., Rakhmani, R.F. (2009). Sogodi Gabdrakhman [Gabdrakhman Sagdi]. Odiplərebez: biobibliografik beleshməlek, 2 tomda: 2 tom. T/z. R. N. Dautov, R. F. Rahmani. Pp. 350-352. Kazan, Tatar.kit.nəshr. (In Tatar)

Səg"di, G. (1926). Tatar ədəbiyaty tarikhy: Doreslek-kullanma [History of Tatar Literature: A Textbook]. 300 p. Kazan, Tatgosizdat. (In Tatar)

Səg"di, G. (1927). Bezda adabi tankyyt' (Yktaberney un"yellygyna) [We Have Literary Criticism (On the $10^{\text {th }}$ Anniversary of the October Revolution).]. 22 p. Kazan, Bezney yul. (In Tatar)

Səg"di, G. (1932). Simvolizm turynda [On Symbolism]. 135 p. Moscow, Tsentrizdat. (In Tatar)

Səg"di Gabdrakhman: fanni-biografik жyyentyk [Sagdi Gabdrakhman: Scientific and Biographical Collection]. Tez. D.Zahidullina, Ch.Gyilaжeva (2008). 416 p. Жyyen. (In Tatar)

Tukai, G. M. (2011). Đsərlər: 6 tomda: 2 t.: shig'ri əsərlər (1909-1913) [Works in Six Volumes: Volume 2: Poetic Works (1909-1913)]. Academik basma. Tez., tekst., isk. həm aңl. əser Z. R. Shəikhelislamov, G. A. Khesnetdinova, E. M. Galimжanova, Z. Z. Rəmiev. 384 p. Kazan, Tatar.kit.nəshr. (In Tatar) 


\section{КИН КОЛАЧЛЫ ГАЛИМ, МЕТОДИСТ ҺӘМ ОСТАЗ}

Таһир Шәмсегали улы Гыйлажев, Казан федераль университеты, Россия, 420008, Казан ш., Кремль ур., 18 нче йорт, tgilazov@bk.ru.

Габдрахман Сәгъди 1889 елның 27 (14) мартында элеккеге Уфа губернасы Златоуст өязе Морзалар волосте (хәзерге Башкортстан Республикасы Салават районы) Таймый авылында (Таими, элекке исеме Атау) руханилар гаиләсендә дөньяга килә. Үз авылында китапханәләр ачып, мөдәррисмөгаллим вазифаларын башкарган Гайнан хажи, укымышлы һәм зыялы кеше булуына карамастан, төпчек улы Габдрахманның уку, аң-белемгә омтылышын хупламый. Атасының каршылыгына карамыйча, ул авыл мәктәбенә йөри башлый, үзсүзлеге аркасында өйдән куып чыгарылган малайга укуга мәхәббәт көч бирә, караңгы тормышын яктырта. Ул 1902 елда Троицкидагы "Рәсүлия" мәдрәсәсенә укырга керә. Матди ярдәмнән мәхрүм ителгән яшүсмер, әүвәл хәллерәк шәкертләргә хезмәт итеп, тамагын туйдыра, каникул вакытларында, казакъ байларына ялланып, акча эшли. Мәгърифәткә омтылыш, зирәклек, тырышып телләр үзләштеру бушка китми, акрынлап шәкертнең үзенә хезмәт итә башлый: ул түбәнрәк белемлеләргә дәресләр бирә, мөгаллимлек һөнәреннән беренче чыныгу үтә.

1908-1911 елларда Төркия дәүләт университетының филология бүлегендә “Төрки-татар әдәбиятлары тарихы" белгечлегеннән югары белем ала, мөмкинлектән файдаланып, башка тармакларны да үзләштерә. Биредә уку еллары Г. Сәгъдинең күзләрен ача: мәгариф системасына үзгәрешләр кертми торып, татар халкының рухи-ижтимагый яңарышына, мәдәни үсешенә ирешеп булмаганлыгына төшенә. Бу яктан аны атаклы мәгърифәтчеләр Каюм Насыйри, Исмәгыйль Гаспралы, Фатих Кәримиләр белән бер рәткә куярга мөмкин. Г. Сәгъди 1910 елда якын киләчәктә тиз арада хәл ителергә тиешле проблемаларны үзәккә куйган “Әдәбиятыбызны мәдрәсәләрдә укыту” дигән мәкаләсен яза. Анда милли зыялылар, шул исәптән үзе алдында торган һәм, Г. Тукай язганча, алар тормышын яктыртып кына калмыйча, эш юнәлешләрен билгеләп, милләткә хезмәткә канатландырып торган “нурлы”, жылы” һәм “мөкатдәс" “идеал уты” [Тукай, 280 б.] билгеләнә.

Зур максатлар белән Төркиядән кайткан Г. Сәгъди фидакарьләрчә эшли башлый һәм һәр ел саен бер методик әсбап яисә монографик хезмәт бастырып чыгара. "Мохтәсар къәвәгыйде әдәбия" (Кыскача әдәбият кагыйдәләре) (1911), “Гыйлавә” (Кушымта) (1911), “Әдәбият ысуллары” (1912), “Әдәбият мөгаллиме” (1913) хезмәтләрендә матур әдәбиятның сәнгать төре буларак үзенчәлеге, асылы, вазифасы, төр һәм жанр, композиция hәм сюжет h.б. мәсьәләләр карала. Г. Сәгъди дәреслекләрендә әлеге проблемалар Төркиядә басылган китаплар үрнәгендә шәрехләнә. Гыйльми-тәнкыйди фикер “Төркиядә белем алу, гарәп-фарсы телләрен өйрәнү, төрек теле hәм әдәбият белеме нигезләре белән танышу, төрек әдәбияты һәм әдәби фикер үрнәкләре белән азыклану, Көнчыгыш галимнәренең хезмәтләрен укып үзләштеру"нең [Галиева, 76 б.] галим нәзари карашлары формалашуга йогынты ясавын билгели.

Татар-рус, татар-европа мәдәни багланышлары көчәйгән заманда, Г. Сәгъди дәреслекләре зур бәхәсләр уята һәм ул, Ү3 позициясен яклап, матбугат битләрендә дистәләгән язмаларын бастыра; тел-әдәбиятны укыту хакында уйланулары, педагогик тәжрибәсе белән уртаклашу нияте белән дә, “Шура" журналында фәнни-методик мәкаләләр циклын тәкъдим итә. Ләкин галим бу ноктада гына чикләнеп калмый, жәдит мәктәпмәдрәсәләр, яңа агымның төрле баскычлары өчен тел гыйлеменең орфография, морфология, синтаксис кебек фәннәреннән дәреслекләр яза, этимология мәсьәләләре белән кызыксына. "Телебезнең нәхүе" (Телебезнең синтаксисы) (1914), "Үз телебездә мөкәммәл сарыф-нәхү" (Yз телебездә тулы морфология-синтаксис) (1915) h.б.лар шундыйлардан.

1917 елгы Октябрь инкыйлабын Г. Сәгъди Бөгелмәдә өч айлык татар-башкорт педагогия курсларында каршылый. Әлеге зат тормышының бу этабы гыйльми-педагогик хезмәттән тыш, оештыру эшләренең активлыгы 
белән характерлана. Аның тырышлыгы аркасында ул өчьеллык педагогия курсларына әйләнә һәм яңадан Бөгелмә Укытучылар семинариесенә нигез салына. Дүрт елга сузылган дәвердә Сәгъди, әдәбият, педогогика, тел һәм әдәбиятны укыту методикасы фәннәреннән дәресләр алып бару белән беррәттән, галимне филология юнәлешеннән башка тармакка алып чыккан “Фәне тәрбия дәресләре” (Педагогика дәресләре) (1918), “Фәне тәрбия вә тәгълим” (Педагогика һәм дидактика) (1918) дәреслекләрен яза. Исеменнән үк күренгәнчә, алар “педагогиканың килеп чыгышы, үсү адымнары, баскычлары, фәннең тармаклары, башка фәннәр белән бәйләнеше, тәрбия теориясе, дидактика кануннары, уку-укыту ысуллары һәм формалары h.б. проблемаларны үз эченә алган" [Гыйләжева, 2012, 21 б.].

Бу елларда зур жаваплылык тойгысы белән, үз-үзен аямыйча эшләү Г. Сәгъдинең сәламәтлеген какшата. Аны ныгыту нияте белән, Кавказдан дәваланып кайтканда, ул Баку шәһәрендә туктала һәм кыска вакытлы педагогик курсларда лекцияләр укый. Шул ук елның көзендә Төркестан республикасының Мәгариф халык комиссариаты аны Ташкентка педагогик хезмәткә чакырып ала. “1921-1925 елларда Г. Сәгъди Ташкентта яши һәм төрки халыклар өчен ачылган Шәрык мәгариф институтында, рабфакларда һәм Урта Азия дәүләт университетында тел-әдәбият укыта. Бер үк вакытта ул үзбәк, казакъ, төрекмән, татар телләрендә чыга торган газетажурналларда төрки әдәбиятлар тарихына караган әдәби-тәнкыйть мәкаләләрен бастыра" [Даутов, Рахмани, 350 б.].

1925 елның көзендә Г. Сәгъди Татарстан Мәгариф халык комиссариаты чакыруы буенча Казанга кайта. Аерым мәгълүматларга караганда, бу гамәлдә галимнең теоретик әзерлеген, фикер куәтенең тирәнлеген югары бәяләгән Г. Ибраһимов та катнашкан. Бу факт, ү3 нәүбәтендә, Сәгъдинең киң колачлы галим белән дустанә һәм ижади мөнәсәбәтләренең тагын да якынаюына китерә, галимнең матур әдәбиятны тикшерү һәм бәяләү методологиясен үзләштерү процессын тизләтә. Ул монда 1930 елга кадәр Татар Коммунистлар университетында, педагогия техникумында татар әдәбияты тарихын укыта. Г. Сәгъди 1926 елда татар теле һәм әдәбияты укытучыларын әзерләүче бердәнбер югары уку йорты саналган Казан Көнчыгыш педагогия институтына доцент итеп сайлана. Бу Г. Сәгъдинең гыйльми hәм оештыру эшчәнлегенең офыкларын киңәйтергә, фәнни эзләнүләрен жәелдерергә мөмкинлекләр бирә. Анда ул татар теле һәм әдәбияты кафедрасын оештыра, шулай ук әдәбият кабинетын ача. Лингвистика, әдәбият белеменең төрле тармакларыннан, методика, педагогика фәннәреннән лекция-дәресләр алып бара. Гыйльми фикерләүгә сәләтле һәм кызыксынучан яшьләрне фәнни эшчәнлеккә тартып, филология юнәлешен, фәннитикшеренү институтларын яңа кадрлар белән тәэмин итүгә үзеннән зур өлеш кертә.

1920-1930 елларда Г. Сәгъди күренекле һәм киңкырлы әдәбият белгече булып житешә. Аның "Татар әдәбияты тарихы" (1926) [Сәгъди, 1926] китабы әдәбият фәненең күтәрелеше, яңа сыйфатта үсеше төсендә бәяләнергә хаклы. Югары уку йортларында филология белгечлеге алучы студентларга дәреслек буларак эшләнгән бу китап әдәбият тарихын тикшерү һәм бәяләү ягыннан монографик хезмәт таләпләренә жавап бирә.

Г. Сәгъди әдәбият тарихыннан монографик хезмәтләр өстендә эшләүдән тыш, әдәбият белеме, аны укытуның актуаль мәсьәләрен үзәккә куйган яки сүз сәнгатенең күренекле вәкилләре ижатына багышланган күпсанлы язмаларын “Безнең юл”, “Мәгариф”, “Кызыл Татарстан" газета-журналларында бастыра. Г. Тукай, Г. Ибраһимов, Ф. Әмирхан, С. Рәмиев, Г.Коләхмәтов h.б.ларга багышланган мәкаләләре әдипләрнең тормыш сукмакларын, ижат эволюциясен яктырту, стиль хасиятләрен ачу ягыннан кызыклы.

1910 елларда әдәби тәнкыйть, аның теоретик проблемаларын аңлау һәм үзләштерүгә замандашлары белән бергә Г.Сәгъди дә тартыла [Гыйлажев, Әдәбият белеменең..., 430 б.]. Бу тармакка “Бездә әдәби тәнкыйть (Үктәбернең ун еллыгына)" [Сәгъди, 1927] дигән хезмәтен багышлый һәм ул кечкенә китапчык булып басылып та чыга. Тәнкыйтьнең барлыкка килү һәм үсү тарихын, поэтик мәсьәләләрен марксистик күзлектән бәяләргә омтылса да, бу тармакның генезисын, үсеш баскычларын, беренчеләрдән булып, билгеле бер системага салып яктырту омтылышында бу хезмәтнең кыйммәте билгеләнә. Әдәби тәнкыйтьнең поэтикасы мәсьәләләренә килгәндә, хезмәт авторы фән һәм тәнкыйть, тәнкыйть һәм нәфис әдәбият, аларның аермасын, әдәби әсәрне бәяләү принципларыннан һәм кагыйдәләреннән 
чыгып, тәнкыйтьнең типларын (“фәлсәфи”, “филологик”), агымнарын (“реалистик”, “идеалистик” (романтик, эстетик)) күрсәтә.

1932 елда Г.Сәгъди фикри егәрлегенең тирәнлеген, акыл эшчәнлегенең киңлеген һәм дә матур әдәбиятны төрле мәдәният, эстетик, фәлсәфи системалар контекстында өйрәнү мөмкинлеген ачкан "Символизм турында" [Сәгъди, 1932] дигән уникаль хезмәте дөнья күрә. Мәскәү шәһәренең үзәк нәшриятында басылып чыгу факты да монографиянең кыйммәте һәм гыйльми дәрәжәсе хакында сөйли. Ул галимнең генә түгел, ә, катлаулы һәм каршылыклы еллар булуга карамастан, татар әдәбият белеменең күтәрелешен күрсәткән житди казаныш булып тора.

Әдәби күренешләрне, язучылар ижатын марксизм-ленинизм эстетикасы ноктасыннан бәяләгән чыгышлар ясауга, гыйльми хезмәтләр яза башлауга карамастан, 1920 елларның ахырында әдәби-гыйльми мохиттә каршылыклар, үзара тартышлар барлыкка килү сәбәпле, Г.Сәгъдигә нахак гаепләр тагу, аның фәнни эшләреннән ялгышлар, идеологик тайпылышлар эзләү көчәйгәннән-көчәя. Үзенең бөтен барлыгын, гомерен фәнгә багышлаган галим бу каршылыклы хәлдән, катлаулы мөнәсәбәтләрдән котылу юлын Урта Азиягә күченеп китүдә таба.

Г.Сәгъди 1930 елда Сәмәркандка барып урнашып, педагогик һәм гыйльми эшчәнлеген Педагогия академиясендә башлап жибәрә. Ике ел эчендә үзбәк әдәбияты каферасын оештыра, тел һәм әдәбият бүлеген ачу мәсьәләләре белән шөгыльләнә. Лекцияләр укудан тыш, сәләтле яшьләрне фәнни hәм ижат эшләренә тарта. Эзләнүчән, тырыш Сәгъди, фәнни-гыйльми киңәшмәләрдә, конференцияләрдә докладлар ясап, үзбәк әдәбият фәненең үсеш юлларын билгели. Утызынчы елларга кадәр язылган проблемалы мәкаләләре һәм чыгышлары “Әдәбият мәсьәләләре һәм Октябрьдән соң үзбәк әдәбияты” (1931) дигән китап шәкелендә басылып чыга. Кызыклы һәм житди хезмәтләре, төпле гыйльми күзаллаулары белән таныла башлаган Г.Сәгьди 1932 елда Ташкентка чакыртып алына һәм югары уку йортларында педагогик эшчәнлек белән шөгыльләнә.

Үзбәкстан СCP Мәгариф халык комиссариаты актив, энергияле һәм тирән белемле Г.Сәгъдине иң авыр учакларда файдалана башлый. 1932 елның көзендә Фирганә дәүләт педагогия институтында үзбәк әдәбияты профессоры гыйльми дәрәжәсе бирелеп, аңа бу уку йортында да үзбәк теле һәм әдәбияты кафедрасын оештыру бурычы йөкләнә һәм галим бу педагогик-методик берәмлекне дүрт ел буена житәкли. Зур оештыру сәләтенә һәм киңкырлы гыйлемгә ия булган бу шәхеснең эше югары бәяләнү сәбәпле, фәнни хезмәтләр язу баскычын читләтеп үтеп, аңа филология фәннәре кандидаты гыйльми дәрәжәсе бирелә һәм янәдән Үзбәк әдәбияты профессоры булып раслана. Г.Сәгъди, үзбәк әдәбияты тарихы һәм аны укыту методикасы тармакларында гыйльми һәм методик эшчәнлеген дәвам итеп, бер-бер артлы “Әдәбияттан кулланма" (1933), "Үзбәк буржуаз әдәбияты" (1934), "Урта мәктәптә әдәбият укыту методикасының төп мәсьәләләре" (1943), "Нәвои - әдәбият галиме hәм тәнкыйтьче" h.б. китапларын нәшер итә [Сәгъди, 2008, 44 б.].

Г. Сәгъди, аңлашылмаучылык аркасында, институттан эштән китәргә мәжбүр була һәм яңадан Сәмәрканд университетына кайта һәм, жиң сызганып, оештыру, гыйльми, педагогик, тәрбия эшләре белән шөгыльләнә башлый. 1937-1941 еллар аралыгында ул Үзбәк дәүләт университетында үзбәк әдәбияты кафедрасын житәкли, студентларга саф үзбәк телендә әдәбият тарихыннан Шәрык фәлсәфәсе, грек мәдәнияте контекстында, бай фактларга таянып, тирән эчтәлекле лекцияләр укый. Бөек Ватан сугышы башланып, Сәмәрканд университеты Ташкенттагы Урта Азия дәүләт университеты белән берләштерелү сәбәпле, Г. Сәгъди дә Ташкентка күчә. Кайда гына булмасын, аңа жаваплы вазифа йөкләнә: тагын ул үзбәк әдәбияты профессоры сыйфатында махсус приказ белән 1942 елдан үзбәк теле һәм үзбәк әдәбияты кафедрасының житәкчесе итеп билгеләнә, үзбәк әдәбияты белеме һәм тел гыйлеме тармакларыннан фәнни кадрлар тәрбияләүгә зур көч куя. Ә инде 1946 елда Г. Сәгъди рәсми төстә "Профессор аттестаты"на ия була. Аның киңкырлы фидакарь хезмәте дәүләт тарафыннан "Хезмәт Кызыл Байрагы” ордены белән бәяләнә.

Югары уку йортында педагогик-методик эшчәнлек белән янәшә Г. Сәгъди 1939-1944 елларда СCCP Фәннәр Академиясенең Үзбәкстан филиалында, 1944-1949 елларда ҮзССР Фәннәр Академиясенең Тел-әдәбият институтында да хезмәттәшлек итә. Аның докторлык диссертациясе "Үзбәк классик әдәбияты үсешендә югары этап буларак Нәвои 
ижаты” (“Творчество Навои, как высший этап в развитии узбекской классической литературы") 1949 нчы елның 6 нчы октябрендә Мәскәүдәге Шәрык институтының Гыйльми Совет утырышында яклана. 1950 нче елның 22 апрелендә ЮАК (ВАК) карары белән Г. Сәгъдигә филология фәннәре докторы дигән гыйльми дәрәжә бирелә" [Гыйләжева, 35 б.].

Г. Сәгъдине язмыш, ижтимагый-тарихи сәбәпләр һәм сәяси вазгыять чит жирләрдә йөртеп, тугандаш халык үзбәк фәненә һәм аның мәдәниятен үстерүгә хезмәт итәргә мәжбүр итсә дә, ул татар халкы, аның әдәби-мәдәни мохите белән һәрдаим кызыксынып яши. Катлаулы, озын һәм дә бәрәкәтле гомеренең соңгы елларында туган ягына кайту теләге булса да, ул тормышка ашмый. 1952 елда СССР Мәдәният министрлыгы фәрманы белән Г. Сәгъди Үзбәк дәүләт университетына үзбәк әдәбияты профессоры гыйльми вазифасы белән эшкә күчерелә һәм, вафат булганчы, шунда хезмәт итә.

Киңкырлы галим M. Госманов, Г. Сәгъдинең "чокыр-чакырлы, сикәлтәле, хәтәр, фажигале" гомер сукмаклары белән татар халкының катлаулы тарихи үткәне арасында параллель үткәреп, галимнең тормышын кинаяле рәвештә "тарихи язмышыбызның бер кыйпылчыгы” [Госманов, 3 б.] дип атый. Димәк, күренекле галим-филолог, тюрколог, методист, педагог-остаз Г. Сәгъди, Сталинның шәхес культы елларында исән калып, XX гасырның беренче утызъеллыгында татар фәне яңарышына hәм туган халкының мәдәни күтәрелешенә, ә 1930 еллардан соң гомеренең соңгы көннәренә кадәр төрки халыклар (төрекмән, казакъ, әзербайжан), аеруча үзбәк әдәбияты һәм теле фәннәре үсешенә, белем бирүнең югары баскычы - институт, университетларда әлеге фәннәрне укыту системасын оештыруга, яшь буын галимнәр тәрбияләүгә үзеннән гажәп дәрәжәдә зур өлеш керткән затлы шәхесләребезнең берсе булып тора.

\section{Әдәбият}

Галиева Э.Р. Татар әдәбият белемендә культуратарих мәктәбе. Казан: Фэн, 2002. 360 б..

Госманов М. Г. Тарихи язмышыбызның бер кыйпылчыгы сыман // Габдрахман Сәгъди: фәннибиографик жыентык / төз. Д.Заһидуллина, Ч.Гыйлажева. Жыен, 2008. 3-6 б.

Гыйлажсев Т.Ш. Әдәбият белеменең бер тармагы буларак әдәби тәнкыйть // Татар әдәбияты тарихы: сигез томда: 4 т.: XX йөз башы / [төз. Р. Ф. Рахмани; фәнни мөх. Р. К. Ганиева]. Казан: Татар.кит.нәшр., 2016. 428-453 б.

Гыйләжева Ч.М. Әдәбият фәне һәм Габдрахман Сәгъди. Казан: РИЦ, 2012. 208 б.

Даутов Р.Н., Рахмани Р.Ф. Сәгъди Габдрахман // Әдипләребез: биобиблиографик белешмәлек: 2 томда: 2 т.: / төз. Р.Н. Даутов, Р.Ф. Рахмани. Казан: Татар.кит.нәшр., 2009. 350-352 б.

Сәгди Г. Татар әдәбияты тарихы: Дәреслеккулланма. Казан: Татгосиздат, 1926. 300 б.

Сәгъди Г. Бездә әдәби тәнкыйть (Үктәбернең унъеллыгына). Казан: Безнең юл, 1927. 22 б.

Сәгъди Г. Символизм турында. М.: Центриздат, 1932. 135 б.

Сәгъди Габдрахман: фәнни-биографик жыентык / төз. Д.Заһидуллина, Ч.Гыйлажева. Жыен, 2008. 416 б.

Тукай Г.М. Әсәрләр: 6 томда: 2 т.: шигьри әсәрләр (1909-1913). Академик басма / төз., текст., иск. һәм аңл. әзер. З.Р.Шәйхелисламов, Г.А. Хөснетдинова, Э.М.Галимжанова, 3.3.Рәмиев. Казан: Татар.кит.нәшр., 2011. 384 б. 